medRxiv preprint doi: https://doi.org/10.1101/2021.03.22.21254081; this version posted March 26, 2021. The copyright holder for this preprint (which was not certified by peer review) is the author/funder, who has granted medRxiv a license to display the preprint in perpetuity.

It is made available under a CC-BY-NC 4.0 International license .

\title{
1 COVID-19 reinfection: A Rapid Systematic Review of Case Reports and Case Series
}

2 Jingzhou Wang, M.D. ${ }^{1}$, Christopher Kaperak, M.D. ${ }^{1}$, Toshiro Sato, M.D., Ph.D. ${ }^{2,3}$, Atsushi Sakuraba, M.D.,

3 Ph.D. ${ }^{4}$

4 1. Department of Internal Medicine, University of Chicago Medicine, Chicago, IL, USA.

5 2. Department of Organoid Medicine, Keio University School of Medicine, Tokyo, Japan.

6 3. Corona Virus Task Force, Keio University School of Medicine, Tokyo, Japan.

4. Section of Gastroenterology, Hepatology, and Nutrition, University of Chicago Medicine,

\section{Corresponding author:}

11 Atsushi Sakuraba, M.D., Ph.D.

12 Director of Clinical Trial/Research

13 Section of Gastroenterology, Hepatology, and Nutrition, The University of Chicago Medicine.

145841 S. Maryland Ave. MC 4076, Chicago, II 60637

15 (Phone) 773-834-0687 (Fax) 773-834-1029

16 (E-mail) asakurab@medicine.bsd.uchicago.edu

17 Sources of Support including grants, fellowships, and gifts of materials: None

18 Potential of conflicts of interest: All authors have no conflicts of interest directly relevant to the content

19 of this article.

20 Author contribution: JW: Methodology (equal); Writing of original draft. CK: Methodology (equal);

21 Writing of original draft (equal). TS: Editing and approval of final draft. AS: Conceptualization;

22 Methodology; Writing, review and editing.

\section{Word count: 890}

24 Key Words: Coronavirus, COVID-19, Reinfection 
medRxiv preprint doi: https://doi.org/10.1101/2021.03.22.21254081; this version posted March 26, 2021. The copyright holder for this preprint (which was not certified by peer review) is the author/funder, who has granted medRxiv a license to display the preprint in perpetuity.

It is made available under a CC-BY-NC 4.0 International license .

\section{Abstract:}

26 The COVID-19 pandemic has infected millions of people worldwide and many countries have been

27 suffering from a large number of deaths. Acknowledging the ability of SARS-CoV-2 to mutate into

28 distinct strains as an RNA virus and investigating its potential to cause reinfection is important for future

29 health policy guidelines. It was thought that individuals who recovered from COVID-19 generate a

30 robust immune response and develop protective immunity, however, since the first case of documented

31 reinfection of COVID-19 in August 2020, there have been a number of cases with reinfection. Many

32 cases are lacking genomic data of the two infections and it remains unclear whether they were caused

33 by different strains. In the present study, we undertook a rapid systematic review to identify cases

34 infected with different genetic strains of SARS-CoV-2 confirmed by polymerase-chain reaction and viral

35 genome sequencing. A total of 17 cases of genetically confirmed COVID-19 reinfection were found. One

36 immunocompromised patient had mild symptoms with the first infection, but developed severe

37 symptoms resulting in death with the second infection. Overall, $68.8 \%(11 / 16)$ had similar severity,

$3818.8 \%(3 / 16)$ had worse symptoms, and 12.5\% (2/16) had milder symptoms with the second episode.

39 Our case series shows that reinfection with different strains is possible and some cases may experience

40 more severe infections with the second episode. The findings also suggest that COVID-19 may continue

41 to circulate even after achieving herd immunity through natural infection or vaccination suggesting the

42 need for longer term transmission mitigation efforts.

43

44 
medRxiv preprint doi: https://doi.org/10.1101/2021.03.22.21254081; this version posted March 26, 2021. The copyright holder for this preprint (which was not certified by peer review) is the author/funder, who has granted medRxiv a license to display the preprint in perpetuity.

It is made available under a CC-BY-NC 4.0 International license.

45 Coronavirus disease 2019 (COVID-19) has infected over 38 million individuals and claimed at least one

46 million lives across the globe since it originated in Wuhan, China in late 2019.(1) As an RNA virus that is

47 prone to mutations, SARS-CoV-2 has been reported to have heterogeneous genetic composition in

48 different geographical locations.(2) Since August 2020, several cases of COVID-19 reinfections have been

49 reported. The current study aims to summarize these cases to facilitate our understanding on the

50 degree of protective immunity.

52 Electronic databases (PubMed, MedRxiv, and Social Science Research Network) were searched from Jan

$531^{\text {st }}, 2020$ to October $12^{\text {th }}, 2020$ using terms "SARS-CoV-2," "CoV2," "COVID-19," and "reinfection".

54 COVID-19 reinfection was defined as individuals infected with different genetic strains of SARS-CoV-2

55 confirmed by polymerase-chain reaction. Only studies with viral genome sequencing available for both

56 infectious events were included in this report to distinguish true re-infection and prolonged viral

57 shedding, as research has shown that a certain proportion of patients may continue to carry the virus

58 despite resolution of symptoms and prior negative PCR tests.(3) For this reason, six peer-reviewed

59 articles and two news articles from the stated date range describing either individual or small groups of

60 additional possible COVID-19 reinfections (totaling 31 individuals) were excluded. The present study was

61 a rapid systematic review of published case reports or case series, so approval of Institutional Review

62 Board (IRB) was not necessary.

63

64 A total of 17 cases of genetically confirmed COVID-19 reinfection have been reported in the literature to

65 date, which are summarized in Table 1. Reinfection has been reported in Asia, Europe, and North and

66 South America. Ages of reinfected individuals ranged between 24 and 89 years old. Mean interval

67 between the first and the second infection averaged 76 days (range 19-142). Only one reinfected patient

68 was immunocompromised $(1 / 17,5.8 \%)$. This patient was a female in her 80 s undergoing chemotherapy 
medRxiv preprint doi: https://doi.org/10.1101/2021.03.22.21254081; this version posted March 26, 2021. The copyright holder for this preprint (which was not certified by peer review) is the author/funder, who has granted medRxiv a license to display the preprint in perpetuity.

It is made available under a CC-BY-NC 4.0 International license .

69 for a hematologic malignancy, who had mild symptoms with her first infection, but developed severe

70 symptoms resulting in death with her second infection.(4) Among the remaining 16 patients, the

71 proportion of patients having mild/asymptomatic infections were the same for the first and second

72 episodes (93.8\%). Overall, 68.8\% (11/16) had similar severity, 18.8\% (3/16) had worse symptoms, and

$73 \quad 12.5 \%(2 / 16)$ had milder symptoms with the second episode.

75 Individuals who recovered from COVID-19 were generally thought to generate a robust immune

76 response to clear the virus. However, it remains to be determined whether the initial infection confers a

77 protective immunity to subsequent infection(s). Recent research has suggested that positive COVID-19

78 antibody from initial infection may provide protection against reinfection in a majority of study

79 participants, but reinfection is still possible in certain individuals. (5) Reinfection with other human

80 coronaviruses is common, despite the presence of antibodies.(6) The current case series indicate that

81 COVID-19 reinfection is possible and the second infection may result in worse symptoms in nearly $20 \%$

82 of patients and serious complications in those who are elderly and immunocompromised. Our data also

83 suggests that reinfection is not specific to any particular strain and multiple strains with different genetic

84 sequence have been shown to cause reinfection. Due to the emergence of the recently described spike

85 deletion variants from UK and South Africa, it is of interest whether second infections can occur in

86 people who have had COVID-19 during the "first wave" before these variants were prevalent.

87

88 Given the potential reporting bias and the current report only including studies with genomic data, there

89 are likely many more reinfection cases than have been currently described. However, the true

90 prevalence of COVID-19 reinfection may be difficult to estimate, considering that complete genomic

91 data is not available in most COVID-19 infections and many patients with milder symptoms were not

92 tested in the early phase of this pandemic. Additionally, people with asymptomatic reinfections are less 
medRxiv preprint doi: https://doi.org/10.1101/2021.03.22.21254081; this version posted March 26, 2021. The copyright holder for this preprint (which was not certified by peer review) is the author/funder, who has granted medRxiv a license to display the preprint in perpetuity.

It is made available under a CC-BY-NC 4.0 International license .

93 likely to be identified, so identifying true prevalence of COVID-19 reinfection is difficult without

94 population-based studies, which is a possible area for future research. Studies included in our analysis

95 reported certain key nucleotide difference between the sequenced viruses, but more recently new

96 variants have also been detected in areas of UK where cases are rising.(7) Some primary literature cited

97 in our study did not contain data on seroconversion, so it is difficult to comment on the connection

98 between immunity and presence of antibody, but one patient developed re-infection despite prior

99 positive antibody test (patient 5). Considering that the two strains belong to the same clade in some

100 reported cases, the possibility of accelerated mutation of the original strain or simultaneous infection

101 with more than one strain in addition to waning immunity should be also considered. It is also difficult to

102 differentiate between COVID-19 reinfection, relapse and PCR re-positivity in some cases and Yahav et al.

103 proposed reinfection as $>90$ days apart(8), but we restricted our inclusion criteria to only patients with

104 confirmed infection with different genetic strains. Two meta-analyses undertaken early in the pandemic

105 reported that reinfection or re-positivity were rare, but lacked cases with genomic data. $(9,10)$

106

107 Our case series indicate that previous COVID-19 exposure does not confer total immunity and that a

108 second infection is possible. Therefore, individuals, regardless of history of prior infection, should

109 continue to participate in mitigating the spread of infection by practicing social distancing and mask

110 wearing. The findings also suggest that COVID-19 may continue to circulate in humans(11), even after

111 achieving herd immunity through natural infection or vaccination. 


\section{Table 1: Summary of COVID-19 Reinfection Cases with Confirmed Genomic Differences}

\begin{tabular}{|c|c|c|c|c|c|c|c|c|c|c|c|c|c|c|}
\hline Patient & $\begin{array}{l}\text { Date } \\
\text { reported }\end{array}$ & $\begin{array}{l}\text { Age } \\
/ \text { sex }\end{array}$ & $\begin{array}{l}\text { Immuno- } \\
\text { compromised }\end{array}$ & $\begin{array}{l}\text { Interval } \\
\text { (d ays) }\end{array}$ & $\begin{array}{l}\text { Symptom } \\
\text { severity }{ }^{\#} \\
\text { (1st episode) }\end{array}$ & $\begin{array}{l}\text { Symptom } \\
\text { severity } \\
\text { (2nd episode) }\end{array}$ & $\begin{array}{l}\text { Negative } \\
\text { PCR test in } \\
\text { between } \\
\text { infections }\end{array}$ & $\begin{array}{l}\text { Seroconversion } \\
\text { after initial } \\
\text { infection }\end{array}$ & $\begin{array}{l}\text { Seroconversion } \\
\text { after second } \\
\text { infection }\end{array}$ & $\begin{array}{l}\text { Viral clade } \\
\left(1^{\text {st }} \text { episode }\right)\end{array}$ & $\begin{array}{l}\text { Viral clade } \\
\left(2^{\text {nd }} \text { episode }\right)\end{array}$ & Recovered & Country & References $\#$ \\
\hline 1 & May-20 & $42 \mathrm{M}$ & No & 51 & Mild & Mild & $\begin{array}{l}\text { Not } \\
\text { performed }\end{array}$ & Not performed & Not performed & B.1.26 & $\begin{array}{l}\text { B. } 1.26 \text { but with } \\
\text { several } \\
\text { mutations }\end{array}$ & Yes & U.S. & $\begin{array}{l}\text { Larson el al, } \\
2020^{8}\end{array}$ \\
\hline 2 & Jun-20 & $25 \mathrm{M}$ & No & 48 & Mild & Moderate ${ }^{\dagger}$ & Yes & Not performed & Yes & $20 \mathrm{C}$ & $\begin{array}{l}20 \mathrm{C} \text { with } 11 \\
\text { SNP mutations }\end{array}$ & Yes & U.S. & $\begin{array}{l}\text { Tillett el al, } \\
2020\end{array}$ \\
\hline 3 & Jun-20 & $51 \mathrm{~F}$ & No & 120 & Mild & Mild & $\begin{array}{l}\text { Not } \\
\text { performed }\end{array}$ & Not performed & Not performed & B.1.1 & A & Yes & Belgium & $\begin{array}{l}\text { Van Elslande el } \\
\text { al, } 2020\end{array}$ \\
\hline 4 & Jul-20 & $60 \mathrm{M}$ & No & 140 & Moderate & Mild & Yes & Not performed & Yes & $19 \mathrm{~B}$ & $20 \mathrm{~A}$ & Yes & U.S. & $\begin{array}{l}\text { Goldman el al, } \\
2020\end{array}$ \\
\hline 5 & Jul-20 & $33 \mathrm{M}$ & No & 142 & Mild & Asymptomatic & Yes & Yes & Yes & $\begin{array}{l}\text { D614 } \\
\text { (V/19A;B.2) }\end{array}$ & $\begin{array}{l}\mathrm{G} 614 \text { (G20A; } \\
\text { B.1) }\end{array}$ & Yes & China & To el al, 2020 \\
\hline 6 & Jul-20 & $46 \mathrm{M}$ & No & 68 & Mild & Mild & Yes & Not performed & Yes & B1.p9 & A.1.1 & Yes & Ecuad or & $\begin{array}{l}\text { Prado el al, } \\
2020\end{array}$ \\
\hline 7 & Jul-20 & $89 \mathrm{~F}$ & Yes & 59 & Mild & Severe $^{\dagger}$ & $\begin{array}{l}\text { Not } \\
\text { performed }\end{array}$ & Not performed & No & N/A & $\begin{array}{l}10 \mathrm{SNP} \\
\text { mutations }\end{array}$ & No & $\begin{array}{l}\text { The } \\
\text { Netherlands }\end{array}$ & $\begin{array}{l}\text { Mulder el al, } \\
2020\end{array}$ \\
\hline 8 & Jul-20 & $27 \mathrm{M}$ & No & 66 & Mild & Mild & Yes & Not performed & No & B.1 & $\begin{array}{l}\mathrm{B} ; 8 \mathrm{SNP} \\
\text { mutations }\end{array}$ & Yes & India & $\begin{array}{l}\text { Shastri el al, } \\
2020\end{array}$ \\
\hline 9 & Jul-20 & $31 \mathrm{M}$ & No & 65 & Asymptomatic & Mild ${ }^{+}$ & Yes & Not performed & No & B.1.1 & $\begin{array}{l}\text { B.1.1; } 9 \text { SNP } \\
\text { mutations }\end{array}$ & Yes & India & $\begin{array}{l}\text { Shastri el al, } \\
2020\end{array}$ \\
\hline 10 & Jul-20 & $27 \mathrm{M}$ & No & 19 & Asymptomatic & Mild + & Yes & Not performed & Not performed & B.1.1 & $\begin{array}{l}\text { B.1.1, } 9 \text { SNP } \\
\text { mutation }\end{array}$ & Yes & India & $\begin{array}{l}\text { Shastri el al, } \\
2020\end{array}$ \\
\hline 11 & Jul-20 & $24 \mathrm{~F}$ & No & 55 & Mild & Mild & $\begin{array}{l}\text { Not } \\
\text { performed }\end{array}$ & Not performed & No & B.1.1 & $\begin{array}{l}\text { B.1.1, } 12 \text { SNP } \\
\text { mutations }\end{array}$ & Yes & India & $\begin{array}{l}\text { Shastri el al, } \\
2020\end{array}$ \\
\hline 12 & Aug-20 & $47 \mathrm{~F}^{*}$ & $\mathrm{~N} / \mathrm{A}$ & 88 & Mild & Mild & $\begin{array}{l}\text { Not } \\
\text { performed }\end{array}$ & Not performed & No & D614 & G614 & Yes & Qatar & $\begin{array}{l}\text { Abu-Raddad el } \\
\text { al, } 2020\end{array}$ \\
\hline 13 & Aug-20 & $27 \mathrm{M}^{*}$ & N/A & 46 & Mild & Mild & $\begin{array}{l}\text { Not } \\
\text { performed }\end{array}$ & Not performed & Not performed & D614 & G614 & Yes & Qatar & $\begin{array}{l}\text { Abu-Raddad } e l \\
a l, 2020\end{array}$ \\
\hline 14 & Aug-20 & $42 \mathrm{M}^{*}$ & $\mathrm{~N} / \mathrm{A}$ & 71 & Mild & Mild & $\begin{array}{l}\text { Not } \\
\text { performed }\end{array}$ & Not performed & Not performed & D614 & G614 & Yes & Qatar & $\begin{array}{l}\text { Abu-Raddad el } \\
\text { al, } 2020\end{array}$ \\
\hline 15 & Aug-20 & $27 \mathrm{M}^{*}$ & N/A & 55 & Mild & Mild & $\begin{array}{l}\text { Not } \\
\text { performed }\end{array}$ & Not performed & Not performed & D614 & G614 & Yes & Qatar & $\begin{array}{l}\text { Abu-Raddad el } \\
\text { al, } 2020\end{array}$ \\
\hline 16 & Aug-20 & $25 \mathrm{M}$ & No & 106 & Asymptomatic & Asymptomatic & Yes & Not performed & Not performed & $\mathrm{N} / \mathrm{A}$ & $\begin{array}{l}9 \mathrm{SNP} \\
\text { mutations }\end{array}$ & Yes & India & $\begin{array}{l}\text { Gupta el al, } \\
2020\end{array}$ \\
\hline 17 & Sep -20 & $28 \mathrm{~F}$ & No & 107 & Asymptomatic & Asymptomatic & Yes & Not performed & Not performed & N/A & $\begin{array}{l}10 \mathrm{SNP} \\
\text { mutations }\end{array}$ & Yes & India & $\begin{array}{l}\text { Gupta el al, } \\
2020\end{array}$ \\
\hline
\end{tabular}

\# Symptom severity were classified as follows: Severe: ICU admission; Moderate: supplemental oxygen with nasal cannula; Mild; no oxygen support but other COVID-19 symptoms (which may include cough, rhinorrhea, sore throat, shortness of breath, change in taste or smell, headache, nausea, vomiting, diarrhea, fever, chills, fatigue, myalgias)

* Only age range was reported in this study, so an average number is taken, i.e. 47 for range 45-49

+ Worse symptoms at second infection compared to the first infection

¥ See full citations in the supplement. 


\section{References:}

1. Medicine JHU. Coronavirus Resource Center. [web site] |. 2020. Available at:

https://coronavirus.jhu.edu/map.html. Accessed Oct 12, 2020.

2. Islam MR, Hoque MN, Rahman MS, et al. Genome-wide analysis of SARS-CoV-2 virus strains circulating worldwide implicates heterogeneity. Sci Rep. 2020; 10:14004.

3. Lan L, Xu D, Ye G, et al. Positive RT-PCR Test Results in Patients Recovered From COVID-19.

JAMA. 2020; 323:1502-1503.

4. Mulder M, van der Vegt D, Oude Munnink BB, et al. Reinfection of SARS-CoV-2 in an immunocompromised patient: a case report. Clin Infect Dis. 2020.

5. V Hall SF, A Charlett, A Atti, EJM Monk, R Simmons, E Wellington, MJ Cole, A Saei, B Oguti, K Munro, S Wallace, PD Kirwan, M Shrotri, A Vusirikala, S Rokadiya, M Kall, M Zambon, M Ramsay, T Brooks, SIREN Study Group, CS Brown, MA Chand, S Hopkins. Do antibody positive healthcare workers have lower SARS-CoV-2 infection rates than antibody negative healthcare workers? Large multi-centre prospective cohort study (the SIREN study), England: June to November 2020. medRxiv. 2021.

6. Galanti M and Shaman J. Direct Observation of Repeated Infections With Endemic Coronaviruses. J Infect Dis. 2020.

7. Wise J. Covid-19: New coronavirus variant is identified in UK. BMJ. 2020; 371:m4857.

8. Yahav D, Yelin D, Eckerle I, et al. Definitions for coronavirus disease 2019 reinfection, relapse and PCR re-positivity. Clinical Microbiology and Infection. 2020.

9. worldometer COVID-19 CORONAVIRUS PANDEMIC [web site] | . Available at: https://www.worldometers.info/coronavirus/. Accessed October 2, 2020.

10. Azam M, Sulistiana R, Ratnawati M, et al. Recurrent SARS-CoV-2 RNA positivity after COVID-19: a systematic review and meta-analysis. Scientific Reports. 2020; 10. 
medRxiv preprint doi: https://doi.org/10.1101/2021.03.22.21254081; this version posted March 26, 2021. The copyright holder for this preprint (which was not certified by peer review) is the author/funder, who has granted medRxiv a license to display the preprint in perpetuity. It is made available under a CC-BY-NC 4.0 International license .

11. To KK, Hung IF, Ip JD, et al. COVID-19 re-infection by a phylogenetically distinct SARScoronavirus-2 strain confirmed by whole genome sequencing. Clin Infect Dis. 2020. 